\title{
IMPLEMENTASI ALGORITMA BOYER-MOORE PADA APLIKASI EATTORIA MERCHANT
}

\author{
Nino Catur Novrianto ${ }^{1}$, Abdul Aziz ${ }^{2}$, Muhammad Priyono Tri $S^{3}$ \\ Teknik Informatika, Universitas Knjuruhan Malang ${ }^{1,2,3}$ \\ caturnovriantonino93@gmail.com
}

\begin{abstract}
Abstrak. Aplikasi “Eattoria Merchant” merupakan wadah pendaftaran pengusaha restoran, cafe dan hingga warung-warung sederhana. Adanya aplikasi "Eattoria Merchant" para usaha lebih mudah mempromosikan produk makanan dan minuman. Seiring dengan hasil analisa dari sebuah system, terdapat kekurangan dalam pencarian produk makanan dan minuman pada aplikasi "Eattoria Merchant”. Saat pencarian produk makanan dan minuman masih menggunakan scroll view. Sehinggga saat mencari produk makanan dan minuman user merasa kesulitan. Karena masih belum adanya fitur pencarian maka peneliti akan menambahkan fitur pencarian produk makanan dan minuman dengan Algoritma Boyer Moore. Sehingga pencarian produk nantinya lebih efisien dalam penggunaannya. Manfaat dari Algoritma Boyer Moore meningkatkan efisiensi suatu proses pencarian produk makanan dan minuman, sehingga produk yang ingin dicari lebih efisien dalam penggunaan. "Eattoria Merchant" ini merupakan wadah pendaftaran pengusaha restoran, cafe dan hingga warung-warung sederhana yang akan diimplementasikan dengan Algoritma Boyer Moore. Tujuan dari penelitian ini adalah mengembangkan "Eattoria Merchant" untuk meningkatkan efisiensi suatu proses pencarian produk makanan dan minuman, sehingga orang yang melakukan proses pencarian produk bisa melihat data yang sudah ada. Berdasarkan dari analisis perbandingan ini proses pencarian produk setelah diterapkan Algoritma Boyer Moore maka pencarian data ini lebih efisien dalam penggunaannya.
\end{abstract}

Kata Kunci: Boyer-Moore; Aplikasi Eattoria Merchant; Analisis Perbandingan.

\section{PENDAHULUAN}

Aplikasi "Eattoria Merchant" merupakan wadah pendaftaran pengusaha restoran, cafe dan hingga warung-warung sederhana. Adanya aplikasi "Eattoria Merchant" para usaha lebih mudah mempromosikan produk makanan dan minuman. Seiring dengan hasil analisa dari sebuah system, terdapat kekurangan dalam pencarian produk makanan dan minuman pada aplikasi "Eattoria Merchant". Saat pencarian produk makanan dan minuman masih menggunakan scroll view. Sehinggga saat mencari produk makanan dan minuman user merasa kesulitan.

Algoritma boyer moore merupakan algoritma yang digunakan untuk melakukan salah satu algoritma pencarian string. Algoritma ini dianggap mencocokkan sebagai algoritma yang paling efisien. Tidak seperti algoritma Knuth-Morris-Pratt, dan algoritma Brute Force. Algoritma Boyer-Moore mulai mencocokkan karakter dari kanan pattern dan bukan dari kiri, maka akan lebih banyak informasi yang didapat.

Berdasarkan penelitian yang dilakukan oleh (Rahmanita, 2014), dalam papernya yang berjudul "Pencarian String Menggunakan Algoritma Boyer Moore Pada Dokumen" menyatakan bahwa Algoritma Boyer Moore mempunyai keunggulan dalam waktu menemukan pattern yang akan dicari dalam ukuran file yang lebih besar dan efektifitas Algoritma Boyer Moore tergantung pada panjang kata yang dicari. Penelitian yang lain (Hakim, Juliana, 2016), dalam papernya yang berjudul "Implementasi Algoritma Boyer Moore Pada Web E-Katalog Flora dan Fauna Pulau Jawa dan Sumatera" yang menyatakan bahwa penerapan algoritma Boyer Moore 
memberikan kemudahan dalam pencarian informasi secara efisien mengenai flora dan fauna Indonesia yaitu khusus Jawa dan Sumatera.

"Eattoria Merchant" masih belum ada fitur pencarian, sehingga saat mencari data produk makanan dan minuman user merasa kesulitan. Karena pada Aplikasi "Eattoria Merchant" yang ada, untuk melihat datanya masih melihat satu-persatu menggunakan scroll view. Oleh karena itu, dalam implementasi algoritma boyer-moore ini berguna untuk efisiensi mencari data yang sudah ada di Aplikasi "Eattoria Merchant" mudah untuk didapatkan, sehingga user dapat mengetahui data produk makanan dan minuman yang sudah pernah di inputkan atau belum oleh pengusaha restoran, cafe dan warung sederhana. Tujuannya Mengembangkan "Eattoria Merchant" untuk meningkatkan efisiensi suatu proses pencarian produk makanan dan minuman. Dengan adanya penelitian di aplikasi "Eattoria Merchant" berbasis android menggunakan Algoritma Boyer - Moore diharapkan memperoleh manfaat Proses Pencarian produk makanan dan minuma lebih efisien.

\section{METODE PENELITIAN}

\section{Rancangan Penelitian}

Penggunaan metode dalam penelitian ini adalah metode eksperimen, dimana metode eksperimen merupakan metode yang menjadi bagian dari metode kuantitatif yang mempunyai ciri khas tersendiri, yaitu dengan adanya kelompok kontrolnya. Desain eksperimen yang digunakan adalah Nonequivalent Control Group Design yang merupakan bentuk metode penelitian eksperimen semu (quasi eksperimen). Desain penelitian disajikan pada Tabel 1.

\begin{tabular}{|c|c|c|}
\hline Kelompok & Perlakuan & Posstest \\
\hline Kelompok eksperimen & Algoritmat boyer-moore & Hasil pencarian \\
\hline Kelompok control & Scroll view & Hasil pencarian \\
\hline
\end{tabular}
cara memberikan perlakuan tertentu pada kelas eksperimen dan menyediakan kelas kontrol. Pencarian produk makanan dan minumnan pada kelas eksperimen memperoleh perlakuan dengan menggunakan metode boyer-moore untuk efisiensi pencarian sedangkan pencarian produk makanan dan minuman pada kelas kontrol memperoleh perlakuan menggunakan scroll view. Pada hasilnya nanti akan terlihat manakah yang lebih efisien anatara kelompok eksperimen dengan kelompok control.

\section{Populasi dan Sampel Penelitian \\ Populasi}

Sugiyono (2012:117) mengungkapkan populasi adalah wilayah generalisasi yang terdiri atas obyek atau subyek yang mempunyai kualitas dan karakteristik tertentu yang ditetapkan oleh peneliti untuk dipelajari dan kemudian ditarik kesimpulannya selanjutnya Arikunto (2010:173) menyebutkan populasi adalah keseluruhan subjek penelitian. Populasi dalam penelitian ini adalah seluruh data produk makanan dan minuman di Warung Lumayan, Jalan Keben 1, Bandungrejosari, Kota Malang, Jawa Timur terdiri dari 2 kelas. Jumlah data produk makanan dan minuman dapat dilihat pada tabel 2. 


\section{RAIINSTEK \\ Jurnal Terapan Sains \& Teknologi}

Vol. 1, No. 4, 2019

Fakultas Sains dan Teknologi - Universitas Kanjuruhan Malang

Tabel 2 Data Produk Makanan dan Minuman

\begin{tabular}{lc}
\hline Kelas & $\begin{array}{c}\text { Jumlah Data Produk } \\
\text { Makanan dan Minuman }\end{array}$ \\
\hline Produk makanan & 6 \\
\hline Produk minuman & 23 \\
\hline Jumlah & 29 \\
\hline
\end{tabular}

Sampel

Menurut Sugiyono (2013:118), sampel adalah bagian dari jumlah dan karakteristik yang dimiliki oleh populasi tersebut. Selanjutnya Arikunto (2010:134) mengemukakan apa bila subyeknya kurang dari 100, lebih baik diambil semua sehingga penelitiannya merupakan penelitian populasi. Berdasarkan penjelasan tersebut, sampel penelitian ini adalah semua populasi dari seluruh data produk makanan dan minuman yang berjumlah 29 .

\section{Definisi Operasional Variabel}

Definisi operasional variabel merupakan penjelasan tentang definisi dari variabel yang diteliti, disertai dengan skala ukur variabelnya, sehingga dapat mencerminkan efisiensi dalam penggunaan pencarian data produk makanan dan minuman manakah yang lebih efesien Antara menggunakan scroll view dengan penerapan algoritma boyer-moore pada aplikasi Eattoria Merchant. Dimana nanti akan dilakuakn percobaan kepada user untuk menilainya. Variabel-variabel yang digunakan dalam penelitian ini adalah:

\section{- Pencarian Scroll View}

Dalam penggunaan pencarian data produk makanan dan minuman untuk melihat datanya masih melihat satu-persatu

- Pencarian Algoritma Boyer-moore

sebagai algoritma pencocokan string yang paling efisien digunakan dalam berbagai aplikasi sehari-hari. Algoritma tersebut dikembangkan oleh Bob Boyer dan J. Stroher Moore pada tahun 1977.

\section{Alat dan Bahan}

Di bawah ini merupakan alat dan bahan yang akan digunakan dalam penelitian, (Tabel 3 alat dan bahan):

\begin{tabular}{lllc}
\multicolumn{4}{c}{ Tabel 3 Alat yang Digunakan Dalam Penelitian } \\
\hline No & Nama Alat & \multicolumn{1}{c}{ Spesifikasi } & Jumlah \\
\hline 1 & Samsung & $\begin{array}{l}\text { Prosesor Octa-core Exynos 5420 } \\
\text { note 3 }\end{array}$ & 1 \\
& & $\begin{array}{l}\text { (terdiri dari empat inti Cortex A15 } \\
1,3 \mathrm{GHz} \text { dan empat inti Cortex A7 }\end{array}$ & \\
& & 1,3Hz) & 1 \\
\hline 2 & Samsung j2 & Quad-core 1.4 GHz Cortex-A53 & 1 \\
& prime & & 1 \\
\hline 2 & Stopwatch & & \\
\hline
\end{tabular}




\section{Pengumpulan Data}

\section{Data Primer}

Data Primer yaitu data yang diperoleh secara langsung dari objek yang teliti, baik dari objek individual (responden) maupun dari suatu instansi yang dengan sengaja melakukan pengumpulan data dari instansi-instansi atau badanlainnya untuk keperluan penelitian dari pengguna (Sugiyono 2017).

\section{Data Sekunder}

Data Sekunder adalah sumber yang tidak langsung memberikan data kepada pengumpulan data, misalnya lewat orang lain atau dokumen (Sugiyono 2017). Data sekunder dapat diperoleh dengan cara membaca, mempelajari dan memahami melalui media lain yang bersumber pada litertur dan data-data yang berkaitan degan masalah data yang sudah ada yang akan diteliti.

\section{Teknik Analisis Data}

Analisis yang digunakan dalam penelitian ini adalah analisis data kuantitatif analisis yang dilakukan dengan menggunakan alat analisis uji deskriptif data, uji normalitas, uji homogen, uji independent sample test. Untuk mengetahui efisiensi dalam penggunaan pencarian data produk makanan dan minuman manakah yang lebih efesien Antara menggunakan scroll view dengan penerapan algoritma boyer-moore pada aplikasi Eattoria Merchant. Dimana nanti akan dilakukan percobaan menggunakan bantuan SPSS versi 24 untuk mengetahui efisien penggunaan dalam pencarian produk di aplikasi Eattoria Merchant.

\section{HASIL ANALISIS}

\section{Deskripsi Data}

Penelitian ini merupakan penelitian eksperimen dengan desain posttest only control design, yaitu menempatkan subyek penelitian ke dalam dua kelompok (kelas) yang dibedakan menjadi kelas eksperimen dan kelas kontrol. Analisis data untuk mengetahui efisiensi proses penggunaan dalam pencarian produk, dilakukan secara kuantitatif. Efisiensi proses penggunaan dalam pencarian produk dapat diketahui dari nilai posttest antara kelas eksperimen dan kelas kontrol yang berbeda.

Sebelum melakukan penelitian dan memperoleh data yang sudah ada dari hasil efisiensi proses penggunaan dalam pencarian produk menggunakan jaringan $3 \mathrm{~g}$, jaringan $2 \mathrm{~g}$, kualitas $\mathrm{hp}$ Samsung note3 dan Samsung j2 prime. Peneliti menguji kedua kelas dimana kelas eksperimen menggunakan boyer-moore dan kelas kontrol menggunakan scroll view dengan jumlah 29 produk. Setelah kedua kelas tersebut diberi perlakuan, selanjutnya diberikan post-test kepada kedua kelas tersebut. Hal ini dilakukan untuk mengetahui efisien proses penggunaan pencarian produk setelah perlakuan.

Untuk memberikan gambaran yang lebih jelas data penelitian dikelompokan berdasarkan kelompok eksperimen dan kelompok control.

Tabel 4 Hasil Kelas Eksperimen Setelah Perlakuan (post-test) dan Kelas Kontrol Sebelum Perlakuan (Post-Test) Samsung Note 3 Kualiatas HP

\begin{tabular}{lll}
\hline & Post-Test Eksperimen & Post-Test Kontrol \\
\hline $\mathrm{N}$ & 29 & 29 \\
\hline Minimum & 1.07 & 1.44 \\
\hline Maksimum & 1.72 & 4.49 \\
\hline Mean & 1.3686 & 2.8355 \\
\hline
\end{tabular}




\section{RAÎNSTEK \\ Jurnal Terapan Sains \& Teknologi}

Vol. 1, No. 4, 2019

Fakultas Sains dan Teknologi - Universitas Kanjuruhan Malang

\begin{tabular}{lll}
\hline Std. Deviasi & .18156 & .82242
\end{tabular}

Berdasarkan tabel 4 di atas setelah perlakuan pada kelas eksperimen didapatkan jumlah $\mathrm{N}$ $=29$, nilai minimum $=1.07$, nilai maksimum $=1.72$, mean $=1.3686$, standar deviasi $=.18156$, dan pada kelas kontrol didapatkan jumlah $\mathrm{N}=29$, nilai minimum $=1.44$, nilai maksimum $=4.49$, mean $=2.8355$, standar deviasi $=.82242$.

Tabel 5 Hasil Kelas Eksperimen Setelah Perlakuan (post-test) dan Kelas Kontrol Sebelum Perlakuan (Post-Test) Samsung J2 Prime Kualiatas HP

\begin{tabular}{lll}
\hline & Post-Test Eksperimen & Post-Test Kontrol \\
\hline $\mathrm{N}$ & 29 & 29 \\
\hline Minimum & 1.32 & 1.85 \\
\hline Maksimum & 2.58 & 6.18 \\
\hline Mean & 1.8500 & 3.8938 \\
\hline Std. Deviasi & .29303 & 1.27049 \\
\hline
\end{tabular}

Berdasarkan tabel 5 di atas setelah perlakuan pada kelas eksperimen didapatkan jumlah $\mathrm{N}$ $=29$, nilai minimum $=1.32$, nilai maksimum $=2.58$, mean $=1.8500$, standar deviasi $=.29303$, dan pada kelas kontrol didapatkan jumlah $\mathrm{N}=29$, nilai minimum $=1.85$, nilai maksimum $=6.18$, mean $=3.8938$, standar deviasi $=1.27049$.

Tabel 6 Hasil Kelas Eksperimen Setelah Perlakuan (post-test) dan Kelas Kontrol Sebelum Perlakuan (Post-Test) Samsung Note 3 Jaringan $3 g$

\begin{tabular}{lll}
\hline & Post-Test Eksperimen & Post-Test Kontrol \\
\hline $\mathrm{N}$ & 29 & 29 \\
\hline Minimum & 1.33 & 2.02 \\
\hline Maksimum & 3.05 & 5.11 \\
\hline Mean & 1.9966 & 3.7217 \\
\hline Std. Deviasi & .48739 & .78755
\end{tabular}

Berdasarkan tabel 6 di atas setelah perlakuan pada kelas eksperimen didapatkan jumlah $\mathrm{N}$ $=29$, nilai minimum $=1.33$, nilai maksimum $=3.05$, mean $=1.9966$, standar deviasi $=.48739$, dan pada kelas kontrol didapatkan jumlah $\mathrm{N}=29$, nilai minimum $=2.02$, nilai maksimum $=5.11$, mean $=3.7217$, standar deviasi $=.78755$.

Tabel 7 Hasil Kelas Eksperimen Setelah Perlakuan (post-test) dan Kelas Kontrol Sebelum Perlakuan (Post-Test) Samsung J2 Prime Jaringan $3 g$

\begin{tabular}{lll}
\hline & Post-Test Eksperimen & Post-Test Kontrol \\
\hline $\mathrm{N}$ & 29 & 29 \\
\hline Minimum & 1.72 & 2.39 \\
\hline Maksimum & 5.32 & 7.39 \\
\hline Mean & 3.0234 & 5.1000 \\
\hline Std. Deviasi & .82146 & 1.27100
\end{tabular}

Berdasarkan tabel 7 di atas setelah perlakuan pada kelas eksperimen didapatkan jumlah $\mathrm{N}$ $=29$, nilai minimum $=1.72$, nilai maksimum $=5.32$, mean $=3.0234$, standar deviasi $=.82146$, dan pada kelas kontrol didapatkan jumlah $\mathrm{N}=29$, nilai minimum $=2.39$, nilai maksimum $=7.39$, mean $=5.1000$, standar deviasi $=1.27100$.

Tabel 8 Hasil Kelas Eksperimen Setelah Perlakuan (post-test) dan Kelas Kontrol Sebelum Perlakuan (Post-Test) Samsung Note 3 Jaringan $2 \mathrm{~g}$ 


\section{RAIINSTEK}

Jurnal Terapan Sains \& Teknologi

Vol. 1, No. 4, 2019

Fakultas Sains dan Teknologi - Universitas Kanjuruhan Malang

\begin{tabular}{lll}
\hline & Post-Test Eksperimen & Post-Test Kontrol \\
\hline $\mathrm{N}$ & 29 & 29 \\
\hline Minimum & 2.06 & 2.22 \\
\hline Maksimum & 3.73 & 7.47 \\
\hline Mean & 2.6976 & 4.7493 \\
\hline Std. Deviasi & .43602 & 1.23662 \\
\hline
\end{tabular}

Berdasarkan tabel 8 di atas setelah perlakuan pada kelas eksperimen didapatkan jumlah $\mathrm{N}$ $=29$, nilai minimum $=2.06$, nilai maksimum $=3.73$, mean $=2.6976$, standar deviasi $=.43602$, dan pada kelas kontrol didapatkan jumlah $\mathrm{N}=29$, nilai minimum $=2.22$, nilai maksimum $=7.47$, mean $=4.7493$, standar deviasi $=1.23662$.

Tabel 9 Hasil Kelas Eksperimen Setelah Perlakuan (post-test) dan Kelas Kontrol Sebelum Perlakuan (Post-Test) Samsung J2 Prime Jaringan $2 g$

\begin{tabular}{lll}
\hline & Post-Test Eksperimen & Post-Test Kontrol \\
\hline $\mathrm{N}$ & 29 & 29 \\
\hline Minimum & 2.11 & 3.07 \\
\hline Maksimum & 7.41 & 11.77 \\
\hline Mean & 4.2917 & 6.6097 \\
\hline Std. Deviasi & 1.31887 & 1.81405
\end{tabular}

Berdasarkan tabel 9 di atas setelah perlakuan pada kelas eksperimen didapatkan jumlah $\mathrm{N}$ $=29$, nilai minimum $=2.11$, nilai maksimum $=7.41$, mean $=4.2917$, standar deviasi $=1.31887$, dan pada kelas kontrol didapatkan jumlah $\mathrm{N}=29$, nilai minimum $=3.07$, nilai maksimum $=11.77$, mean $=6.6097$, standar deviasi $=1.81405$.

\section{Pengujian Persyaratan Analisis}

\section{Uji Normalitas}

Uji normalitas dilakukan untuk menguji apakah semua variabel berdistribusi normal atau tidak. Uji normalitas menggunakan rumus Kolmogorov-Smirnov dalam perhitungan menggunakan program SPSS 24. Untuk mengetahui normal tidaknya adalah jika sig > 0,05 maka normal dan jika sig $<0,05$ dapat dikatakan tidak normal. Hasil perhitungan yang diperoleh sebagai berikut:

Tabel 10 Hasil Uji Normalitas Data Posttest Samsung Note 3 dan Samsuung J2 Prime Kualiatas Hp

\begin{tabular}{|c|c|c|c|c|}
\hline No & $\mathrm{Hp}$ & Kelas & Sig & Kesimpulan \\
\hline \multirow{2}{*}{1} & \multirow{2}{*}{ Samsung note3 kualitas hp } & Ekperimen & .200 & Normal \\
\hline & & Kontrol & .200 & Normal \\
\hline \multirow{2}{*}{2} & \multirow{2}{*}{ Samsung j2 prime kualitas hp } & Ekperimen & .200 & Normal \\
\hline & & Kontrol & .200 & Normal \\
\hline
\end{tabular}

Kriteria pengujian :

Jika signifikansi (Sig) $>\propto(0.05)$, maka berdistribusi normal

Jika signifikansi (Sig) $<\propto(0.05)$, maka tidak berdistribusi normal

Berdasarkan perhitungan uji normalitas kualitas hp Samsung note3 pada kelas eksperimen diperoleh $\mathrm{Sig}=0.200$ dan kelas kontrol diperoleh $\mathrm{Sig}=0.200$. Dengan 


\section{RAIINSTEK \\ Jurnal Terapan Sains \& Teknologi}

Vol. 1, No. 4, 2019

Fakultas Sains dan Teknologi - Universitas Kanjuruhan Malang

membandingkan dengan nilai $\propto=0.05$, maka diperoleh untuk kelas eksperimen $\operatorname{Sig}=0.200>$ $\propto(0.05)$ dan untuk kelas kontrol Sig $=0.200>\propto(0.05)$. Sehingga dapat disimpulkan bahwa kedua data tersebut berdistribusi normal. Sedangkan perhitungan uji normalitas Samsung j2 prime pada kelas eksperimen diperoleh Sig $=0.200$ dan kelas kontrol diperoleh Sig $=0.200$. Dengan membandingkan dengan nilai $\propto=0.05$, maka diperoleh untuk kelas eksperimen Sig $=$ $0.200>\propto(0.05)$ dan untuk kelas kontrol Sig $=0.200>\propto(0.05)$. Sehingga dapat disimpulkan bahwa kedua data tersebut berdistribusi normal.

Tabel 11 Hasil Uji Normalitas Data Posttest Samsung Note 3 dan Samsung J2 Prime Jaringan $3 g$

\begin{tabular}{|c|c|c|c|c|}
\hline No & $\mathrm{Hp}$ & Kelas & Sig & Kesimpulan \\
\hline \multirow{2}{*}{1} & \multirow{2}{*}{ Samsung note 3 jaringan $3 g$} & Ekperimen & .126 & Normal \\
\hline & & Kontrol & .200 & Normal \\
\hline \multirow{2}{*}{2} & \multirow{2}{*}{ Samsung j2 prime jaringan $3 g$} & Ekperimen & .139 & Normal \\
\hline & & Kontrol & .200 & Normal \\
\hline
\end{tabular}

Kriteria pengujian :

Jika signifikansi (Sig) $>\propto(0.05)$, maka berdistribusi normal

Jika signifikansi (Sig) $<\propto(0.05)$, maka tidak berdistribusi normal

Berdasarkan perhitungan uji normalitas Samsung note3 jaringan $3 \mathrm{~g}$ pada kelas eksperimen diperoleh $\mathrm{Sig}=0.126$ dan kelas kontrol diperoleh $\mathrm{Sig}=0.200$. Dengan membandingkan dengan nilai $\propto=0.05$, maka diperoleh untuk kelas eksperimen $\mathrm{Sig}=0.126>$ $\propto(0.05)$ dan untuk kelas kontrol Sig $=0.200>\propto(0.05)$. Sehingga dapat disimpulkan bahwa kedua data tersebut berdistribusi normal. Sedangkan perhitungan uji normalitas Samsung j2 prime jaringan 3g pada kelas eksperimen diperoleh Sig $=0.139$ dan kelas kontrol diperoleh $\mathrm{Sig}=$ 0.200. Dengan membandingkan dengan nilai $\propto=0.05$, maka diperoleh untuk kelas eksperimen SIg $=0.139>\propto(0.05)$ dan untuk kelas kontrol Sig $=0.200>\propto(0.05)$. Sehingga dapat disimpulkan bahwa kedua data tersebut berdistribusi normal.

Tabel 12 Hasil Uji Normalitas Data Posttest Samsung Note 3 dan Samsung J2 Prime Jaringan $2 g$

\begin{tabular}{ccccc}
\hline \multirow{2}{*}{ No } & $\mathrm{Hp}$ & Kelas & Sig & Kesimpulan \\
\hline \multirow{2}{*}{1} & Samsung note3 jaringan $2 \mathrm{~g}$ & Ekperimen & .200 & Normal \\
\cline { 3 - 5 } & \multirow{2}{*}{2} & Kontrol & .200 & Normal \\
\hline \multirow{2}{*}{ Samsung j2 prime jaringan 2g } & Ekperimen & .200 & Normal \\
\cline { 3 - 5 } & & Kontrol & .200 & Normal \\
\hline
\end{tabular}

Kriteria pengujian :

Jika signifikansi (Sig) $>\propto(0.05)$, maka berdistribusi normal

Jika signifikansi (Sig) $<\propto(0.05)$, maka tidak berdistribusi normal

Berdasarkan perhitungan uji normalitas Samsung note3 jaringan $2 \mathrm{~g}$ pada kelas eksperimen diperoleh Sig $=0.200$ dan kelas kontrol diperoleh $\mathrm{Sig}=0.200$. Dengan 
membandingkan dengan nilai $\propto=0.05$, maka diperoleh untuk kelas eksperimen Sig $=0.200>$ $\propto(0.05)$ dan untuk kelas kontrol Sig $=0.200>\propto(0.05)$. Sehingga dapat disimpulkan bahwa kedua data tersebut berdistribusi normal. Sedangkan perhitungan uji normalitas Samsung j2 prime jaringan $2 \mathrm{~g}$ pada kelas eksperimen diperoleh $\mathrm{Sig}=0.200$ dan kelas kontrol diperoleh $\mathrm{Sig}=$ 0.200. Dengan membandingkan dengan nilai $\propto=0.05$, maka diperoleh untuk kelas eksperimen Sig $=0.200>\propto(0.05)$ dan untuk kelas kontrol Sig $=0.200>\propto(0.05)$. Sehingga dapat disimpulkan bahwa kedua data tersebut berdistribusi normal.

\section{Uji Homogenitas}

Setelah diketahui tingkat kenormalan data, maka selanjutnya dilakukan uji homogenitas. Uji homogenitas digunakan untuk mengetahui tingkat kesamaan varians antara dua kelompok yaitu kelompok eksperimen dan kelompok kontrol. untuk menerima atau menolak hipotesis dengan membandingkan harga sig pada levene's statistic dengan 0,05 ( sig > 0,05) Hasil uji homogenitas dapat dilihat pada tabel berikut:

Tabel 131 Hasil Uji Homogenitas Data Posttest Samsung Note 3 dan Samsung J2 Prime Kualiatas Hp

\begin{tabular}{ccccc}
\hline No & Hp & Kelas & Sig & Kesimpulan \\
\hline \multirow{2}{*}{1} & Samsung note3 kualitas hp & eksperimen dan kontrol & 0.000 & Tidak Homogen
\end{tabular}

\section{Samsung j2 prime kualitas hp eksperimen dan kontrol $0.000 \quad$ Tidak Homogen}

\section{Kriteria pengujian : \\ Jika nilai signifikansi (Sig) $>\propto(0.05)$, maka homogen \\ Jika nilai signifikansi (Sig) $<\propto(0.05)$, maka tidak homogen}

Berdasarkan tabel di atas, kualitas hp Samsung note3 nilai Sig posttest antara kelas eksperimen dan kelas kontrol diperoleh sig $=0.000$. Dengan menbandingkan dengan nilai $\propto=$ 0.05 , maka untuk Sig $=0.000>\propto(0.05)$, sehingga dapat disimpulkan bahwa data tersebut berasal dari populasi dengan varians yang tidak (homogen). Sedangkan kualitas hp Samsung j2 prime nilai Sig posttest antara kelas eksperimen dan kelas kontrol diperoleh $\mathrm{Sig}=0.000$. Dengan menbandingkan dengan nilai $\propto=0.05$, maka untuk Sig $=0.000>\propto(0.05)$, sehingga dapat disimpulkan bahwa data tersebut berasal dari populasi dengan varians yang tidak (homogen).

Tabel 14 Hasil Uji Homogenitas Data Posttest Samsung Note 3 Jaringan $3 g$

\begin{tabular}{ccccc}
\hline No & Hp & Kelas & Sig & Kesimpulan \\
\hline 1 & Samsung note3 jaringan 3g & eksperimen dan kontrol & 0.019 & Tidak Homogen \\
\hline
\end{tabular}

\section{Samsung j2 prime jaringan 3g eksperimen dan kontrol 0.007 Tidak Homogen}

\section{Kriteria pengujian :}

Jika nilai signifikansi $(\mathrm{Sig})>\propto(0.05)$, maka homogen

Jika nilai signifikansi (Sig) $<\propto(0.05)$, maka tidak homogen

Berdasarkan tabel di atas, Samsung note3 jaringan $3 \mathrm{~g}$ nilai Sig posttest antara kelas eksperimen dan kelas kontrol diperoleh Sig $=0.019$. Dengan menbandingkan dengan nilai $\propto=$ 0.05 , maka untuk Sig $=0.019>\propto(0.05)$, sehingga dapat disimpulkan bahwa data tersebut berasal dari populasi dengan varians yang (homogen). Sedangkan Samsung j2 prime jaringan $3 g$ nilai Sig 


\section{RAIINSTEK \\ Jurnal Terapan Sains \& Teknologi}

Vol. 1, No. 4, 2019

Fakultas Sains dan Teknologi - Universitas Kanjuruhan Malang

posttest antara kelas eksperimen dan kelas kontrol diperoleh $\mathrm{Sig}=0.007$. Dengan menbandingkan dengan nilai $\propto=0.05$, maka untuk Sig $=0.007>\propto(0.05)$, sehingga dapat disimpulkan bahwa data tersebut berasal dari populasi dengan varians yang tidak (homogen).

Tabel 15 Hasil Uji Homogenitas Data Posttest Samsung Note 3 dan Samsung J2 Prime Jaringan $2 g$

\begin{tabular}{ccccc}
\hline No & Hp & Kelas & Sig & Kesimpulan \\
\hline \multirow{2}{*}{1} & Samsung note3 jaringan 2g & eksperimen dan kontrol & 0.000 & Tidak Homogen \\
\hline
\end{tabular}

2 Samsung j2 prime jaringan $2 \mathrm{~g}$ eksperimen dan kontrol $0.236 \quad$ Homogen

\section{Kriteria pengujian :}

Jika nilai signifikansi (Sig) $>\propto(0.05)$, maka homogen

Jika nilai signifikansi (Sig) $<\propto(0.05)$, maka tidak homogen

Berdasarkan tabel di atas, Samsung note3 jaringan $2 \mathrm{~g}$ nilai Sig posttest antara kelas eksperimen dan kelas kontrol diperoleh $\mathrm{Sig}=0.000$. Dengan menbandingkan dengan nilai $\propto=$ 0.05 , maka untuk Sig $=0.000>\propto(0.05)$, sehingga dapat disimpulkan bahwa data tersebut berasal dari populasi dengan varians yang tidak (homogen). Sedangkan Samsung j2 prime nilai Sig posttest antara kelas eksperimen dan kelas kontrol diperoleh $\mathrm{Sig}=0.236$. Dengan menbandingkan dengan nilai $\propto=0.05$, maka untuk $\operatorname{Sig}=0.236>\propto(0.05)$, sehingga dapat disimpulkan bahwa data tersebut berasal dari populasi dengan varians yang sama (homogen).

\section{Pengujian Hipotesis}

Setelah dilakukan uji normalitas dan uji homogenitas data dari hasil posttest diketahui bahwa penyebaran skor posttest kelas eksperimen dan kontrol berdistribusi normal sehingga untuk menguji perbedaan dua rerata posttest digunakan uji statistik parametrik uji t. Uji t (Independent Samples T Test) dengan bantuan program SPSS 24, dengan taraf signifikansi 5\% dapat dilihat pada tabel berikut:

Tabel 16 Hasil Uji t Posttest Samsung Note 3 dan Samsung J2 Prime Kualiatas Hp

\begin{tabular}{cclcc}
\hline No & Hp & \multicolumn{1}{c}{ Kelas } & Mean & Sig (2-taled) \\
\hline \multirow{2}{*}{1} & $\begin{array}{c}\text { Samsung Note } 3 \\
\text { kualiatas hp }\end{array}$ & Post-Test Kelas Eksperimen & 1.3686 & .000 \\
\cline { 3 - 5 } & Post-Test Kontrol & 2.8355 & .000 \\
\hline \multirow{2}{*}{2} & $\begin{array}{c}\text { samsung j2 } \\
\text { prime kualitas } \\
\text { hp }\end{array}$ & Post-Test Kelas Eksperimen & 1.8500 & .000 \\
\cline { 3 - 5 } & Post-Test Kontrol & 3.8938 & .000 \\
\hline
\end{tabular}

Berdasarkan tabel di atas menunjukkan bahwa, kualias hp Samsung note3 nilai mean post-test pada kelas eksperimen $=1.3686$ dan nilai mean pada kelas control $=2.8355$. Karena nilai Sig $=.000<\propto(0.05)$. Hal ini menunjukan ada perbedaan antara hasil post-test kelas eksperiment dan post-test kelas kontrol. Artinya dapat disimpulkan bahwa proses penggunaan pencarian produk menggunakan algoritma boyer-moore efiesien dari pada proses penggunaan pencarian produk menggunakan scroll view. Sedangkan kualitas hp Samsung j2 prime nilai mean post-test pada kelas eksperimen $=1.8500$ dan nilai mean pada kelas control $=3.8938$. Karena nilai Sig $=.000<\propto(0.05)$. Hal ini menunjukan ada perbedaan antara hasil post-test kelas 
eksperiment dan post-test kelas kontrol. Artinya dapat disimpulkan bahwa proses penggunaan pencarian produk menggunakan algoritma boyer-moore efiesien dari pada proses penggunaan pencarian produk menggunakan scroll view.

Tabel 17 Hasil Uji t Posttest Samsung Note 3 dan Samsung J2 Prime Jaringan 3g

\begin{tabular}{|c|c|c|c|c|}
\hline No & $\mathrm{Hp}$ & Kelas & Mean & Sig (2-taled) \\
\hline \multirow{2}{*}{1} & \multirow{2}{*}{$\begin{array}{c}\text { Samsung Note } 3 \\
\text { jaringan } 3 \mathrm{~g}\end{array}$} & Post-Test Kelas Eksperimen & 1.9966 & .000 \\
\hline & & Post-Test Kontrol & 3.7217 & .000 \\
\hline \multirow{2}{*}{2} & \multirow{2}{*}{$\begin{array}{c}\text { samsung j2 } \\
\text { prime jaringan } \\
3 \mathrm{~g}\end{array}$} & Post-Test Kelas Eksperimen & 3.0234 & .000 \\
\hline & & Post-Test Kontrol & 5.1000 & .000 \\
\hline
\end{tabular}

Berdasarkan tabel di atas menunjukkan bahwa, Samsung note 3 jaringan $3 \mathrm{~g}$ nilai mean post-test pada kelas eksperimen $=1.9966$ dan nilai mean pada kelas control $=3.7217$. Karena nilai Sig $=.000<\propto(0.05)$. Hal ini menunjukan ada perbedaan antara hasil post-test kelas eksperiment dan post-test kelas kontrol. Artinya dapat disimpulkan bahwa proses penggunaan pencarian produk menggunakan algoritma boyer-moore efiesien dari pada proses penggunaan pencarian produk menggunakan scroll view. Sedangkan Samsung j2 prime jaringan $3 \mathrm{~g}$ nilai mean post-test pada kelas eksperimen $=3.0234$ dan nilai mean pada kelas control $=5.1000$. Karena nilai Sig $=.000<\propto(0.05)$. Hal ini menunjukan ada perbedaan antara hasil post-test kelas eksperiment dan post-test kelas kontrol. Artinya dapat disimpulkan bahwa proses penggunaan pencarian produk menggunakan algoritma boyer-moore efiesien dari pada proses penggunaan pencarian produk menggunakan scroll view.

Tabel 18 Hasil Uji t Posttest Samsung Note 3 dan Samsung J2 Prime Jaringan 2g

\begin{tabular}{ccccc}
\hline No & $\mathrm{Hp}$ & \multicolumn{1}{c}{ Kelas } & Mean & Sig (2-taled) \\
\hline \multirow{2}{*}{1} & $\begin{array}{c}\text { Samsung Note 3 } \\
\text { jaringan 2g }\end{array}$ & Post-Test Kelas Eksperimen & 2.6976 & .000 \\
\cline { 3 - 5 } & Post-Test Kontrol & 4.7493 & .000 \\
\hline \multirow{2}{*}{2} & $\begin{array}{c}\text { samsung j2 } \\
\text { prime jaringan } \\
2 \mathrm{~g}\end{array}$ & Post-Test Kelas Eksperimen & 4.2917 & .000 \\
\cline { 3 - 5 } & & Post-Test Kontrol & 6.6097 & .000 \\
\hline
\end{tabular}

Berdasarkan tabel di atas menunjukkan bahwa, Samsung note3 jaringan $2 \mathrm{~g}$ nilai mean post-test pada kelas eksperimen $=2.6976$ dan nilai mean pada kelas control $=4.7493$. Karena nilai Sig $=.000<\propto(0.05)$. Hal ini menunjukan ada perbedaan antara hasil post-test kelas eksperiment dan post-test kelas kontrol. Artinya dapat disimpulkan bahwa proses penggunaan pencarian produk menggunakan algoritma boyer-moore efiesien dari pada proses penggunaan pencarian produk menggunakan scroll view. Sedangkan Samsung j2 prime jaringan $2 \mathrm{~g}$ nilai mean post-test pada kelas eksperimen $=4.2917$ dan nilai mean pada kelas control $=6.6097$. Karena nilai Sig $=.000<\propto(0.05)$. Hal ini menunjukan ada perbedaan antara hasil post-test kelas eksperiment dan post-test kelas kontrol. Artinya dapat disimpulkan bahwa proses penggunaan pencarian produk menggunakan algoritma boyer-moore efiesien dari pada proses penggunaan pencarian produk menggunakan scroll view. 


\section{PEMBAHASAN}

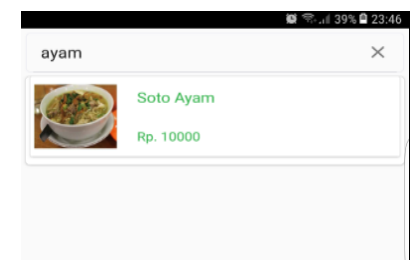

Gambar 1 Hasil Pencarian Produk

Dari hasil analisis yang dilakukan, menggunakan kualitas hp Samsung note3 dengan jumlah produk $(\mathrm{N})=29$ item. Nilai mean post-test pada kelas eksperimen $=1.3686$ dan nilai mean pada kelas control $=2.8355$. Karena nilai $\mathrm{Sig}=.000<\propto(0.05)$ maka hasilmya signifikan. Hal ini menunjukkan ada perbedaan Antara hasil post-test eksperimen dan post-test kontrol. Dengan demikian dapat dikatakan bahwa proses penggunaan pencarian produk menggunakan algoritma boyer-moore lebih efisien dari pada scroll view.

Dari hasil analisis yang dilakukan, menggunakan kualitas hp Samsung j2 prime dengan jumlah produk $(\mathrm{N})=29$ item. Nilai mean post-test pada kelas eksperimen $=1.8500$ dan nilai mean pada kelas control $=3.8938$. Karena nilai $\mathrm{Sig}=.000<\propto(0.05)$ maka hasilmya signifikan. Hal ini menunjukkan ada perbedaan Antara hasil post-test eksperimen dan post-test kontrol. Dengan demikian dapat dikatakan bahwa proses penggunaan pencarian produk menggunakan algoritma boyer-moore lebih efisien dari pada scroll view.

Dari hasil analisis yang dilakukan, menggunakan Samsung note3 jaringan $3 \mathrm{~g}$ dengan jumlah produk $(\mathrm{N})=29$ item. Nilai mean post-test pada kelas eksperimen $=1.9966$ dan nilai mean pada kelas control $=3.7217$. Karena nilai Sig $=.000<\propto(0.05)$ maka hasilmya signifikan. Hal ini menunjukkan ada perbedaan Antara hasil post-test eksperimen dan post-test kontrol. Dengan demikian dapat dikatakan bahwa proses penggunaan pencarian produk menggunakan algoritma boyer-moore lebih efisien dari pada scroll view.

Dari hasil analisis yang dilakukan, menggunakan Samsung j2 prime jaringan $3 \mathrm{~g}$ dengan jumlah produk $(\mathrm{N})=29$ item. Nilai mean post-test pada kelas eksperimen $=3.0234$ dan nilai mean pada kelas control $=5.1000$. Karena nilai Sig $=.000<\propto(0.05)$ maka hasilmya signifikan. Hal ini menunjukkan ada perbedaan Antara hasil post-test eksperimen dan post-test kontrol. Dengan demikian dapat dikatakan bahwa proses penggunaan pencarian produk menggunakan algoritma boyer-moore lebih efisien dari pada scroll view.

Dari hasil analisis yang dilakukan, menggunakan Samsung note3 jaringan $2 \mathrm{~g}$ dengan jumlah produk $(\mathrm{N})=29$ item. Nilai mean post-test pada kelas eksperimen $=2.6976$ dan nilai mean pada kelas control $=4.7493$. Karena nilai Sig $=.000<\propto(0.05)$ maka hasilmya signifikan. Hal ini menunjukkan ada perbedaan Antara hasil post-test eksperimen dan post-test kontrol. Dengan demikian dapat dikatakan bahwa proses penggunaan pencarian produk menggunakan algoritma boyer-moore lebih efisien dari pada scroll view.

Dari hasil analisis yang dilakukan, menggunakan Samsung j2 prime jaringan $2 \mathrm{~g}$ dengan jumlah produk $(\mathrm{N})=29$ item. Nilai mean post-test pada kelas eksperimen $=4.2917$ dan nilai mean pada kelas control $=6.6097$. Karena nilai Sig $=.000<\propto(0.05)$ maka hasilmya signifikan. Hal ini menunjukkan ada perbedaan Antara hasil post-test eksperimen dan post-test kontrol. Dengan demikian dapat dikatakan bahwa proses penggunaan pencarian produk menggunakan algoritma boyer-moore lebih efisien dari pada scroll view. 


\section{RAIINSTEK \\ Jurnal Terapan Sains \& Teknologi}

Vol. 1, No. 4, 2019

Fakultas Sains dan Teknologi - Universitas Kanjuruhan Malang

Selain hasil analisis di atas ada perbedaan dari kualitas $\mathrm{hp}$, jaringan $3 \mathrm{~g}$ dan $2 \mathrm{~g}$ juga memepengaruhi proses penggunaan pencarian produk. Dengan demikian dikatakan bahwa penggunaan algoritma boyer-moore efisien dalam pencarian produk makanan dan minuman dari pada algoritma yang lainnya. Menurut (Utomo, Harjo, Handoko, 2008) algoritma Boyer Moore paling cepat dibandingkan dengan Karp Rabin, Knuth-Morris-Pratt, dan Brute Force.

Penelitian ini dari segi pelaksanaan teknis maupun dalam pengumpulan data eksperimen masih manual menggunakan stopwacth, pada jaringan $3 \mathrm{~g}$ dan $2 \mathrm{~g}$ jaringannyan masih tidak stabil. Maka untuk peneliti selanjutnya diharapkan dapat mengatasi keterbatasan tersebut.

\section{PENUTUP}

\section{Kesimpulan}

Berdasarkan permasalahan, tujuan penelitian, hasil analisis dan pembahasan yang telah dipaparkan, Dengan demikian dapat disimpulkan bahwa algoritma boyer-moore efisien dalam pencarian produk makanan dan minuman dari pada scroll view.

\section{Saran}

Berdasarkan hasil penelitian yang diperoleh, peneliti merekomendasikan untuk dijadikan bahan pertimbangan dan pemikiran. Bagi peneliti selanjutnya diharapkan dalam pengumpulan data eksperimen tidak manual, supaya pengambilan data lebih akurat.

\section{DAFTAR RUJUKAN}

Agung, H., \& Yogyawan. (2016). IMPLEMENTASI BOYER-MOORE PADA APLIKASI Pencarian Rumus Matematika dan Fisika. JITTER, III(I), 74-85.

Argakusumah, K. W., \& Hansun, S. (2014). Implementasi Algoritma Boyer-Moore pada Aplikasi Kamus Kedokteran Berbasis Android. Jurnal ULTIMATICS, 6(2), 70-78. https://doi.org/10.31937/ti.v6i2.340

Ayu Permatasari Siahaan, M. (2018). Kamus Nama Bayi Beserta Maknanya. Pelita Informatika, $17,97-101$.

Darmawan dan Setianingrum, A. (2018). Implementasi Algoritma Boyer Moore Pada Aplikasi Kamus Istilah Kebidanan Berbasis Web. QUERY, II(April), 53-62.

Dermawan Utomo, Eric Wijaya Harjo, H. (2008). Perbandingan Algoritma String Searching Brute Force, Knuth Morris Pratt, Boyer Moore, dan Karp Rabin Pada Teks Alkitab Bahasa Indonesia. Tenche Jurnal Ilmiah Elektroteknika, 7, 1-13.

Hakim, L. H., \& Juliana, V. (2016). Implementasi Algoritma Boyer Moore Pada Web E-Katalog Flora Dan Fauna Pulau Jawa Sumatera. Jurnal Ilmiah FIFO, 8(1), 52. https://doi.org/10.22441/fifo.v8i1.1300

Kejora, F. D., Astuti, E. S., \& Rozi, I. F. (2016). Boyer-Moore Berbasis Android. Seminar Informatika Aplikatif Polinema.

Rahmanita, E. (2014). Pencarian String Menggunakan. Nero, 1(1), 15-26.

Ramadhansyah. (2013). Perancangan Aplikasi Kamus Bahasa Gayo Dengan Menggunakan Metode Boyer-Moore. Jurnal Pelita Informatika Budi Darma, IV(12110817), 118-122.

Rohmat Indra Borman, Agus Pratama, K. (2016). Penerapan String Matching Dengan Algoritma Boyer Moore Pada Aplikasi Font Italic. TEKNOINFO, 10(2), 1-5. 
Fakultas Sains dan Teknologi - Universitas Kanjuruhan Malang

Sagita, V., \& Prasetiyowati, M. I. (2013). Studi Perbandingan Implementasi Algoritma Boyer-Moore, Turbo Boyer-Moore, dan Tuned Boyer-Moore dalam Pencarian String. Jurnal ULTIMATICS, 5(1), 31-37. https://doi.org/10.31937/ti.v5i1.311 